\title{
A Rethinking of Children at Stake. Musings for their Revaluation
}

\section{Un replanteamiento en la noción de las y los niños en juego. Reflexiones para su revalorización}

\author{
Sonia París Albert ${ }^{1}$ \\ Universitat Jaume I (España) \\ Joanna Haynes ${ }^{2}$ \\ University of Plymouth (Inglaterra)
}

Recibido: 07-02-19

Aprobado: 24-04-19

\begin{abstract}
A rethinking of children is necessary, particularly in Western societies, where a Modern conception has prevailed, based on ideas of children's fragility, vulnerability and dependence on adults. This Modern conception has

\footnotetext{
${ }^{1}$ (sparis@uji.es). PhD. Sonia París is a lecturer of Philosophy in the Department of Philosophy and Sociology at Universitat Jaume I (UJI), Castellon, Spain. She is the Vice-Director of the UNESCO Chair of Philosophy for Peace and the Coordinator of the International Master's Degree in Peace, Conflict and Development Studies at UJI. She has done research at University of San Francisco and at the Universidad Autonoma del Estado de México, Toluca, Mexico. Her research areas are Philosophy for Peace, Conflict Studies, Philosophy with Children and Creativity. Her latest publications are: París Albert, S.: "Philosophy for making peace with children. An incentive for creativity", Convergencia. Revista de Ciencias Sociales, 75 (2017) 65-85. París Albert, S.: "Mutual recognition in Axel Honneth's Philosophy; contributions to the peaceful conflict transformation", Pensamiento. Revista de investigación e información filosófica, 74, 280 (2018) 369-385. París Albert, S.: "Educational actions to face some challenges of Philosophy in the XXI Century", Daimon. Revista Internacional de Filosofia, 74 (2018) 105-119.

ORCID: https://orcid.org/0000-0003-1326-5078.

2 (joanna.haynes@plymouth.ac.uk). PhD. Joanna Haynes is Associate Professor in Education Studies at Plymouth University Institute of Education. She has taught in all phases of education, from pre-school to university, and in informal learning and community settings. Her scholarly activity and interests are in Philosophy for Children, philosophy of childhood and education, and dangerous or difficult knowledge. Her first book, Children as Philosophers (2002), has been translated into several languages. She recently co-edited The Routledge International Handbook of Philosophy for Children (2017). Joanna is a collaborator in the international De/colonizing Childhood Discourses in Higher Education project https://www.decolonizingchildhood.org/ and co-editor, with Karin Murris, of a book published about this research: Literacies, Literature and Learning: reading classrooms differently (2018).
}

ORCID: https://orcid.org/0000-0003-0510-4565. 
emphasized the notion of life as a process divided into identificable stages and has considered age as the main criterion to identify what it is to be a child and an adult. In front of this conception, this text proposes the objective of recuperating the alternatives offered by both Postmodern theory and Posthumanism, in order to propose a revaluation of children as empowered creative subjects, who, in dialogue to adults and in relation with more-than-humans (animals and things), will be understood as co-educators. To that end, pedagogies that give priority to children's creativity and to their critical and ethical thinking will be emphasized, making particular connection to the school of Philosophy with Children and the methodology based on picturebooks.

Key-words: Children, Creativity, Philosophy with Children, Picturebooks, Critical Thinking; Ethical Thinking.

\section{Resumen}

Un replanteamiento de los niños es necesario, particularmente en las sociedades occidentales, donde ha prevalecido una concepción moderna basada en su fragilidad, vulnerabilidad y dependencia de los adultos. Una concepción moderna que ha enfatizado la noción de vida como un proceso dividido en etapas identificables, y que ha considerado la edad como el principal criterio para decir lo que es ser niño y adulto. Frente a esta concepción, este texto propone recuperar las alternativas ofrecidas por la teoría posmoderna y el posthumanismo, a fin de revalorizar a los niños como sujetos creativos empoderados, quienes, en diálogo con los adultos y en relación con los más-que-humanos (animales y cosas), serán entendidos como co-educadores. Con ese fin, se enfatizarán las pedagogías que priorizan la creatividad de los niños y su pensamiento crítico y ético, haciendo conexión especial con la escuela de Filosofía con Niños y la metodología de los cuentos con imágenes.

Palabras-clave: Niños, creatividad, Filosofía con Niños, cuentos con imágenes, pensamiento crítico, pensamiento ético.

\section{Introduction $^{3}$}

Contemporary societies require a revision of the notion of children through which both the discourses and relationships based on adult authority are questioned. So much so that it is necessary to imagine and work for the possibility of overcoming the Modern paternalist conception of children, based

3 This study was funded by the University Jaume I under grant number UJI-B2019-13 "Comunicación para el cambio social y educación mediática frente a los discursos del odio sobre género o inmigración: análisis de los discursos públicos en el periodo 2016-2019”. 
on their fragility and vulnerability, as pure and innocent subjects. In this sense, the Postmodern notion of children revaluates them as resourceful subjects, able to take decisions from their own points of view, as well as understanding life as a continuous movement, in which children and adults cannot be completely separated. The Postmodern conception leaves aside, then, the Modern perception of life as maturational process with closed identificable stages. Furthermore, beyond the Postmodern notion of children, there is a current Posthumanist theory that breaks down the Modernist idea of fully-human and includes the expression of more-than-human to dislodge the human from the centre of all relations.

This paper sets out to review Modern, Postmodern and Posthumanist discourses of children with the main objective of rethinking children, paying special attention to the following three proposals: 1) children can be understood as empowered subjects in dialogue with adults; 2) children can be perceived as critical and ethical thinkers thanks to their creative ways of acting; 3) children can be identified as co-educators in the framework of alternative pedagogies in which creativity takes a priority position. These three proposals create the structure of the paper and put the rethinking of children at stake.

\section{Rethinking children as empowered subjects in dialogue with adults}

When adults talk about children, there is often a definition that comes quickly to mind according to which children are understood as lacking experience, deficient, vulnerable, dependent and incapable of coherent thinking (Huynh et al. 2015: 37). This can be attributed to the dominance of the general trend of Modernity that categorizes children as both pure and innocent subjects (Kennedy 2006: 80). This definition, conceived in Modernity, ${ }^{4}$, continues to exert influence and which, for most current researchers in childhood studies, makes sense of the articles of the Convention of the Rights of the Child, approved by The United Nations in November 1989 (United Nations 1989), in which the notion of children refers to subjects under the age of 18. A definition that takes the criterion of age to distinguish children from adults, provoking a perception that encloses children in a concrete period of life (Kohan 2011: 341) whose main objective is to prepare them for their adulthood (Storme and Vliegue 2011: 184). So, the

${ }^{4}$ It is important to mention that the perception of children in Modernity was very influenced by both Platon and the idea of the original sin of the Middles Ages. By Platon because he defended, in The Republic, the need of an external person (philosopher or educator), who had to take charge of giving form to a subject who didn't have it and who was unable to give it by herself/himself (Kohan 2011: 340). By the idea of the original sin of the Middles Ages because, as the original sin talked about the weak children by nature, a strict discipline for them, controlled by adults, was needed (Gittins 1998: 23; Kennedy 2006). Certainly, the original sin provoked a big revolution in the conception of children when it introduced the idea that adults had to protect children, which victimized them and made them dependent subjects (Gittins 1998: 111).

Araucaria. Revista Iberoamericana de Filosofia, Política, Humanidades y Relaciones Internacionales, año $22, \mathrm{n}^{\circ} 43$. Primer semestre de 2020. Pp. 197-214. ISSN 1575-6823 e-ISSN 2340-2199 https://dx.doi.org/10.12795/araucaria.2020.i43.09 
question of time becomes fundamental in this Modern perception of children, which is widely influenced by an interpretation of the life as a process divided into identificable stages, being childhood one of these stages. In fact, Matthews (1996: 16) affirms that child development is understood here as a "maturational process" sequenced in stages that are based on the age.

The claim of differentiating adults from children is absolutely visible in this Modernist conception. Based on the idea that children are the opposites of adults (Murris 2016a), it defines the first in opposition to the second, prioritizing their negative differences instead of their positive ones. This is the reason why it describes children as subjects with poor physical, psychological, emotional, intellectual and social development, so they cannot be as autonomous and responsible as adults (Huynh et al. 2015). Therefore, an image of children as they really are, is not revealed here (Murris 2016a: 60) because, actually, children are understood as potential adults with the need to develop those that are considered as the characteristics of adulthood if they want to become fullpeople (Pávez Soto 2012: 87). According to Matthews (1996: 27), it is a gaze that dehumanizes children when it both prioritizes more their future than their present and conceives of children living "in a pre-rational" and, very especially, "in a pre-scientific world" (27). A pre-rational or pre-scientific world identified by some sociological analyses, like those done by both Durkheim and Parsons, as a pre-adult stage or a pre-social one where the social mechanisms, through which children will become adults, is very important, due to the notion of sponge children that prevails here (Pávez Soto 2012: 83). For instance, Parsons emphasizes the need for punishment and rewards in response to the behavior of children (86).

Paternalism is behind this Modernist conception of children, which has been called the caretaker thesis by Huynh, D'Costa and Lee-Koo (2015: 37), with the objective of highlighting children's dependence on adults because of an image based on their not-yet-full-development that focus all the attention on children's vulnerability, incompetence, innocence and ignorance $(39,47)$. In this sense, under paternalism, children need to be protected by adults for two main reasons: firstly, they are so impressionable, fickle, egocentric and unable to plan their future that they can neither take well-organized decisions nor be responsible of their acts (Huynh et al. 2015: 39, 40). In fact, Kennedy (2006: 59) says that children are perceived here as fools; as the representation of nature versus culture that is represented by adults. Secondly, the world does not seem to be thought of as being for children, but only for adults. All things are made to a bigger size than children, so they live as if they were always surrounded by giants (Matthews 1996: 22, 23), and this is what makes adults think that a child can only be a complete citizen in the future, not in her/his present. 
This persisting Modernist idea, in which the emphasis is on children's deficiencies, leads us to refer to this conception as Deficit Theory (Haynes and Murris 2013a: 217; Kennedy 2006). Children's enclosure in a concrete stage of life leads to Developmentalist Theories (Murris 2016a) where an essentialist way of understanding children is found, based on capitalist discourses that relate maturity to the adult white heterosexual man taking into account the idea of natural development ${ }^{5}$ (Murris 2017a). In this sense, Murris (2017a) affirms, for instance, that this notion of children can be connected to colonization and imperialism, because it locates children in the same social position than other minority groups, as black people, women, slaves, etc.

An alternative notion to the perception of children related in the previous paragraphs is emerging now in order to go beyond Modernist conceptions, which begins its approach from two particular statements: 1) The Modern conception of children, that continues to persist, is constructed from Modern Western societies. 2) As a consequence, this social construction universalizes the notion of children and childhood and prevents us from perceiving children in different ways according to the diversity of cultures around the world (Burman 2008; Huynh et al. 2015: 44). These two statements aim to recognize the plurality and the complexity in the definition of children and enable us to consider how Modernity has universalized the perception of Western societies with the end of both imposing it on other cultures and denying different possible ways of understanding children. This Postmodernist alternative affirms, for instance, the important roles as workers, fighters or peace-makers that children also play in some places where conflicts are part of their lives. So, taking into account these criticisms, a new conception of children as free-rangers (Huynh et al. 2015: 44) is proposed here, whereby children are not perceived as malleable, ignorant, passive and absolutely dependent on adults, but as agentic, rich, resilient and resourceful subjects (Murris 2016a). Characteristics of children that are recovered, then, when the Postmodern alternative proposes to overcome the Modern notion of life as a maturational process, where there are closed identificable stages that distinguish clearly children from adults with the objective to promote a notion of life as a continuous movement, in which children and adults can't be absolutely separated (Huynh et al. 2015: 50; Matthews 1996: 16). Both children and adults change continuously and have the possibility of sharing characteristics as well as of learning from each other. For this reason, an exploration of their traits is necessary for this alternative (Huynh et al. 2015: 51). In this sense, the capacity to fantasize (Murris 2000a: 262), the ability to play (Smith 2011), freshness, inventiveness (Matthews 1996), spontaneity, plasticity, creativity, imagination and enthusiasm (Kennedy 2006) are usually related to children while the discipline and the rigor

${ }^{5}$ Some of the new sociology of childhood notions of Developmentality tied up with neo-liberal capitalist discourses and practices, too (Hultqvist and Dahlberg 2001).

Araucaria. Revista Iberoamericana de Filosofia, Política, Humanidades y Relaciones Internacionales, año $22, \mathrm{n}^{\circ} 43$. Primer semestre de 2020. Pp. 197-214. ISSN 1575-6823 e-ISSN 2340-2199 https://dx.doi.org/10.12795/araucaria.2020.i43.09 
(Matthews 1996) are often used to define adults. A set of characteristics that make us recognize both children and adults in their individuality, but always in dialog (Kennedy 2006), it is, in a dialogical relation in which they can share some traits and learn each from other. According to these ideas, firstly, children don't have to be compared to adults any more (Matthews 1996) or perceived as an incomplete form of adult's subjectivity, but as engaged in "an alternative epistemology" (Kennedy 2006: 98), able to experience the world from the point of view of children, not of adults, with a particular form of life (Murris 1999) that empowers them to create the meanings of their worlds (Huynh et al. 2015: 44 ), although always in dialogue with adults. Secondly, adults are seen as having the potential for change, with the capacity for transformation (Pávez Soto 2012: 88), not as complete subjects unable to learn anything else. Adults can learn from children a different view of the world and, being in contact with children, they can recover the child who they were (Kennedy 2010). The latter idea, widely discussed by Kennedy $(2013 ;$ 2014) within a Neoteny Theory framework, with which he defends the maintenance of the above mentioned characteristics of children in adults in order to emphasize the possibility of taking out the child within when they are influenced by children (Kennedy 2006: 159).

Therefore, both children and adults are subjects-in-process here (Kennedy 2006), whose life is a continuous movement where the ones can be influenced by the others, so that the usual characteristics related to children are conceived as a precise force that can be found during all life (Kohan 2011: 342). Related to these ideas, Haynes and Murris (2013a: 218) highlight the relevance of recognizing the voices of children, empowering them as co-educators and, in the same way, Alderson (2016) propounds an intergenerational equity, respect and care with the objective to overcome the notion of children as pre-citizens under the power of adult-centered politics (6). It is then, a strong recognition of children's voices and rights that leads us to rethink them as empowered active rational agents, capable of critical and ethical thinking, too (Matthews 1996; Vansieleghem and Kennedy 2011: 172).

\subsection{Posthumanist theory: children in intra-action with more-than-human}

The influence on childhood studies of the Postmodernist alternative analysed in the previous section has been enormous, to such an extent that a big revolution in the conception of children has been provoked. Nevertheless, new theories, which aim to go beyond the Postmodern alternative, are emerging nowadays, as we can see, for instance, in Murris's Posthumanist proposal (Murris 2016a). Murris wants to avoid the categorization of children through a recognition of the different ways of understanding them, thanks to a revaluation of the situation of each child in her/his context. However, 
the challenge to the Postmodern alternative in Posthumanist theory is really observed when the human is removed from the centre in order to put in its place the intra-action between human and more than human (animals and things) (Murris 2015; 2016a: 46). Strongly influenced by feminist physicist Karen Barad, Murris (2016b) considers that human beings exist in conjunction with other bodies (Murris 2016b: 278), which leads her to affirm that, actually, the "posthuman subject" appears in intra-action, what does not mean that she/ he pre-exist in its relations with the others (289). This is an assertion that the author makes with the objective of asserting the mutual relationality between human and more than human, although taking always into account, on one hand, the subjectification ${ }^{6}$ of each body and, on the other, the agency and the dynamic character of matter (282).

The use of the concept of intra-action instead of interaction is very important in Posthumanist theory (Murris 2017a). In fact, Murris uses this concept because she considers that interaction refers to both nature and culture as pure, as two states in relation, but not affected the one by the other. In this sense, if we apply this conception to children, we will understand them as subjects in relation to other humans, animals and things, but not affected by them. By contrast, Murris says that intra-action refers to bodies (humans and more than humans), which exist in their subjectification, although being influenced always by one another as a result of the mutual relationality existing among all of them. This is the main reason why Murris (2017a) identifies each body as an entanglement in which all its influences are together, giving rise to a unique piece as a thick network.

Therefore, as we can clearly show, the value of the intra-action between humans and more than humans (animals and things) is very important in Posthuman theory, and helps us to appreciate the following two issues: 1) The role of matter when the theory recognizes its agency and its influences on human beings, through the emphasis put on their mutual relationality. 2) The subjectification of each body in intra-action, that brings Murris to prioritize the children's voices as unique and irreplaceable (Murris 2017b). From these ideas, Posthumanist theory attempts to break down the Modernist conception of fullyhuman (Murris 2017a), and, at the same time, goes beyond the Postmodern alternative by taking into account the more-than-human, removing the human from the centre and promoting a notion of a postdevelopmental child perceived as an entanglement of social and political influences (Murris 2016a).

\footnotetext{
${ }^{6}$ When Murris talks about subjectification, she is influenced by Biesta, who distinguishes three levels to be worked in the formal education: qualification, socialization and subjectification (Murris 2017b). Both Biesta and Murris prioritise the subjectification as an opportunity to recover children's voices.
} 


\section{Rethinking children as critical and ethical subjects thanks to their creativity}

The alternative conception of children analyzed in the first section of this paper allows us to put into play a rethinking of children as active subjects (Kennedy 2006; Murris 2016a: 82) with critical, ethical and creative thinking, three competences, identified, for instance, by Lipman as the main three parts of the human capacity for thinking. Taking into account this priority, and to help the coherence of this text, we include here a definition of each of these three competences: critical thinking as that, which leads us to express our opinions about the texts that we read, the images that we see and/or the words that we hear (Pritchard 1998: 74-75); ethical thinking as that which lets us empathize with others, humans and more than humans, recognizing different points of view on a same question (Greene 1995); and creative thinking as that which enables us to produce new, more or better ideas (Csikszentmihalyi 1996), thanks to our continuous connections with the experience (París Albert 2017: 78).

Basing their studies on these definitions, many researchers have affirmed that children are creative thinkers. However, their assertions have been very different when they have talked about children's competences to think critically and ethically. This perception is a result of the way in which children relate to the world according to their perspectives, based, very especially and as already mentioned in this paper, on their tendency to play (Murris 2008; 2016a), their curiosity and originality (Haynes and Murris 2013a), their freshness (Murris 2000a: 271) and spontaneity (Kennedy 2006), their continuous questions (Kennedy 2010) and their unexpected answers (Murris 1999). These are a set of characteristics, which have usually been used to distinguish their behaviors and attitudes from adults, as well as to affirm that, therefore, children are neither critical thinkers nor ethical ones. On the contrary, the aim of this paper is to understand, precisely, these characteristics as those that also favour children's critical and ethical thinking, due to their inescapable relation to children's creativity and, as a consequence of that, their valuable promotion of children's opportunities to express their opinions from different points of view, imagining new alternatives and empathizing with others, humans and more than humans. For this reason, we consider, then, that children's critical and ethical thinking benefits from their creativity as it is their constant desire to experience and to play with new ideas (Murris 2008) that makes possible for them to produce, effortlessly, new, more and better thoughts.

We are saying, therefore, that children can be rethought as critical and ethical thinkers, but always from their (diverse and situated) perspectives as children, which are, above all, based on their creative ways to relate to the world. 
In this sense, it is absolutely vital to take into account the necessity to revaluate them from their own languages; from their capacity to fantasize (Murris 2000a: 262), this doesn't mean to be less rational than adults, but only that children do not have to be compared to them anymore (Matthews 1996) because, as Murris says, doing this comparison, researchers are not comparing apples with apples, but they are comparing apples with pears (Murris 2000a: 262). For Kennedy (2010), children are critical thinkers by nature that act according to their freshness and inventiveness, that lets us define them as imaginative thinkers (Matthews 1996: 18), who should establish a necessary dialogue with adults through which everyone could learn from the other at the same time that children would become the valuable strangers (Kennedy 2010). It means that children would become the natives that, without having the same experience in the daily life as adults, which would lead them to monopolize a unique comprehension of the world as superior, have, therefore, more possibilities of acting creatively, imagining different ways of understanding things.

A school of thought, which works very much in line with the conception of child described above, is Philosophy with Children, introduced by Lipman, Sharp and other researchers in the seventies (Vansieleghem and Kennedy 2011) as a critical pedagogy that generates authentic transformative experiences of thought. This approach, which has had some variations since its origins with Lipman and others, very especially, when its name changed from Philosophy for children to Philosophy with children, (Kohan 2011; Vansieleghem and Kennedy 2011: 178), assumes the schools are spaces where children can actively participate in contexts that have an important meaning for them (Wilson 1992: 287), leading to greater appreciation of all voices involved in the learningteaching process. In this sense, it can be defined as a transformative pedagogy (Haynes and Murris 2009: 183) that has gained in popularity because of its innovative methodologies, procedures, materials, etc. As a consequence of that, we consider it relevant here, not to do a broad analysis of its characteristics, but to emphasize the following three questions, which are very pertinent to the topics of the paper.

1) Philosophy with children recognizes children as critical and ethical thinkers with its defence of their capacity to philosophize. There are authors who work very hard to deconstruct the assertions that children cannot philosophize due to their "cognitive limitations" (Kitchener 1990: 427). These authors defend, on the one hand, that these assertions are based on a reductionist conception of philosophy, which takes us to understand it as a body of knowledge only, not as a favorable activity for the practice of philosophize (Murris 2000a; 2008). Conceptualized as an activity, there is no doubt for these researchers that philosophy can help people to both practice and develop their capacity to reflect and to communicate, their critical, ethical and collaborative 
thinking, their intellectual and social virtues, their honesty, modesty, respect and patience as well as their sensibility towards the differences (Wilson 1992: 289-290). On the other hand, authors affirm, too, that the perception of children as subjects, who cannot do philosophy, is an effect of the comparison between adults and children. According to this, Murris (1999: 23) says that the practice of Philosophy by adults in academia should not be the paradigm to identify the ways of philosophizing by children because, as children relate their activities to games very easily (Smith 2011: 222), they actually philosophize as if they were playing, to the point that they can easily get to compare the rules of games to the ways of putting into practice their moral conduct (222), giving many forms to their philosophical practice. These ideas are which lead Matthews (Murris 2000a: 266) to consider that adults could become "better philosophers" if they kept "the natural innocence" that children have.

Taking into account the value of all voices in the continuous dialogues generated through narrative forms of enquiry, Philosophy with Children works through the community of philosophical enquiry. In this community, while children are philosophizing, they can put into practice their critical and ethical thinking from their own points of view, turning into action these competences and promoting the possibility of rethinking them as critical and ethical thinkers. In summary, with these dialogues, collaboration between children and adults is produced (Kennedy 2010; Murris 2000b) and children's perspectives are re-evaluated through the practice and the development of their "social and democratic skills", their competences for moral deliberation and their capacity "for thinking critically, reflectively and reasonably" (Biesta 2011: 306). Dialogues encourage children "to be curious, to puzzle, to be surprised" as well as to question things in order to generate a discussion (Haynes and Murris 2009: 183) where they can build their arguments in dialogue with the ideas of others, an unaccustomed way of acting and talking in both education and society in general (Murris 2000b: 40). Therefore, for Haynes and Murris (2009: 176), there is no doubt that philosophical enquiry is a favorable teaching mechanism, thanks to which children increase their confidence in their capacities as "meaning makers".

2) Philosophy with children works from children's creativity to rethink them as critical and ethical subjects. In this paper, we believe that children's creativity, based on their ability to look at the events of the world from unusual perspectives and to imagine unexpected answers to understand them, is valued as the starting point in the school of thought associated with Philosophy with Children. This is the reason why we consider that children's creative thinking acquires a privileged position here, due to the relevance given to both the promotion of children's questions and the original ways in which they build these questions as the main tools to develop the practice of their critical and 
ethical thinking. In fact, we can say that, while children are questioning the things around them, they do it from their capacity to fantasize, that enables them to imagine these things from more than one creative perspective, also putting themselves in the place of the others, humans and more than humans. So, in order to facilitate the promotion of children's critical an ethical thinking, Philosophy with Children pays special attention to the practice of creativity, also working on it through its materials and methodologies, with the objective of enhancing it in children more and more, so that it doesn't get turned off, but it becomes a habit, which will last through childhood and into adulthood, also blurring the boundaries between these positions.

According to these ideas, there is a concrete current approach in the framework of Philosophy with Children based on picturebooks (Haynes and Murris 2012), which, whilst inspired by Lipman's curriculum, also aims to go beyond the uniformity of its analytical reason (Murris 2016c). In this sense, Murris (2016d) says that it is so because Lipman created a set of sequential novels that were considered as unique and necessary models for all children depending on their age and, above all, for all teachers with little philosophical training. They were, then, novels with pre-designed philosophical contents to be worked according to children's age, which required a teachers' broad philosophical formation to be able to deal with the topics introduced in each novel (Murris 2016d). Instead of that, the picturebooks approach doesn't work with purpose written novels, but it is based on open-ended visual works of children's literature (Murris 2014), which, through both words and images, provoke philosophical dialogues about a wide range of non-pre-designed contents, at the same time that encourage children to inquire creatively about possible fantastic scenarios for both the real and the imaginary world (Murris 2016c). The fact of having an open ending is very important, as it provides children with the possibility of exploring more than one creative way of understanding the picturebook (Haynes and Murris 2013b; Murris 2016c). Thus, children get a very active role here, thanks to their freedom to question, to argue critically and ethically from their creativity, to play with the ideas and to imagine more alternatives for the things that happened in the stories (Haynes 2007). Besides, children become co-responsible for their learning with teachers, who, although not being experts in the philosophical fields, must have competences and dispositions to guide the dialogues. One way to proceed, that leads children to include the complexity, the emotions and the imagination in their critical and ethical arguments, is to provoke creative questions which can't be answered easily and to make familiar what it is strange (Haynes and Murris 2013b).

In summary, picturebooks become a means to re-value children's creativity for practicing and developing their critical and ethical thinking. In this sense, 
they take into account that the competences of children to be creative are always more interesting than adults think (Olsson 2013), due to their capacity to imagine, very especially, when they are philosophizing (Murris 2016a). So, creativity is approached in picturebooks from a philosophical point of view, so that it acquires an extraordinary, unpredictable and inexplicable character (Kronfeldner 2009: 577), at the same time that it promotes attentiveness, recognition, tolerance, commitment, dedication, a will to change, etc. (Schipper 2001: 11).

3) Philosophy with children enriches a perception of children as critical, ethical and creative subjects in dialogue with adults. In the previous pages of this article, we have already talked about the necessary dialogue that has to be established between children and adults in all contexts, including in the field of formal education, with the main objective of giving greater recognition to children as critical, ethical and creative thinkers, capable of building their own knowledge. In this sense, for instance, Haynes and Murris (2009: 176), in the framework of their philosophical practice with children, highlight the following three actions to achieve this greater recognition of children voices. 1) The creation of an intellectual and emotional space for children's questions and their continuous class contributions. 2) The inescapable necessity of having teachers with an appropriate training in listening during the children's dialogues as well as in the formulation of the pertinent questions to guide children to create their own ideas. 3) The recognition of each child as a critical, ethical and creative subject, able to express her/his thoughts and to develop her/his participation in her/his learnings and in her/his diary life. It is, therefore, to engage in dialogues in which both children and adults are revaluated, taking into account their possible mutual influences, as, not only adults can influence children, but children can offer adults new critical and ethical perspectives from their creativity too (Matthews 1996; Murris 2016a).

As we have already mentioned, one author who has worked deeply on the relevance of children-adults-dialogues has been Kennedy (2006) with his proposal for a Neoteny Theory, which emphasizes the possibility of maintaining the child that people carry inside during adulthood, thanks to a dialogue between both the adults' fixed structure, characterized by the habit, and the children's emergent one, based on impulse (Kennedy 2013; 2014). So, taking Dewey's concepts of habit and impulse, Kennedy prioritizes the relation between, on the one hand, the habit in adults, given by their longer experience, that causes some pre-built ontological convictions, as implicit epistemological beliefs, truths, rules, attitudes and concrete ways to relate to others and, on the other hand, the impulse in children, given by their shorter experience, that makes it possible for them to have the desire to explore, to create new things, to talk and to communicate and to express their feelings and thoughts. 
What we would like to defend in this paper, therefore, is that the practice of Philosophy with Children favors these reciprocal dialogues between children and adults, that lets us understand children as subjects able to be influenced by adults, due to their ability to imitate them, as well as subjects that, from their critical, ethical and creative points of view, can have enormous influences on adults, too. So, according to the objectives of this text, the Philosophy with Children benefits our understanding of children as co-educators (Haynes and Murris 2013a: 218) and our understanding of their capacity for questioning, seeing, striving, their wide-eyed, curiosity and excitement as permanent childlike characteristics of the human species (Kennedy 2013; 2014). This enriches the possibility of rethinking them as empowered subjects in dialogue with adults, with critical and ethical thinking thanks to their creativity.

\section{Rethinking children as co-educators in pedagogies for a creativity revaluation}

The idea discussed in this paper, according to which, a rethinking of children as co-educators is put at stake, is very important if we take into account that it presupposes many changes in possible ways of understanding their social participation. Specially, it implies a great transformation in the conception of schools, which could begin to be more identified as transitional spaces where there would not be adult domination of children anymore (Kennedy 2010), but an increasing equality, reciprocal recognition and care among all agents implied during the process of learning-teaching (Alderson 2016).

This notion of schools as transitional spaces, linked to the alternative conception of children outlined in the previous sections, brings with it pedagogies that overcome the more traditional ones, based, above all, on the technique of narration. With narration, teachers, as "statutory authorities" (Bourdieu and Passeron 1990: 109), deposit the contents on passive students, who attend classes with the main idea of listening and assimilating the teacher's messages and without many attempts at participation. Teachers control, for the most part, the teaching-learning process, as it is they who choose the contents to be transmitted, what has priority, and how they have to be transferred. There are, therefore, two clearly opposing positions in the most traditional pedagogies, the privileged position of teachers in front of the secondary position of children, thanks to a methodology that, turns students into "containers", who have to memorize the content explained by the teacher (Freire 1972: 45).

These traditional pedagogies, named, for instance, by Freire (1972; 1994; 2004) as banking education, can be related, to the traditional conception of children, with their influences from Piaget's theory (Murris 2000a), according 
to which, as it is understood that children development goes through different stages, and that the content of subjects has to be introduced depending on age. It is how age becomes the main criterion at the time of deciding if children are prepared to study some subjects or not.

It is very important to say here that, although these traditional pedagogies continue in many schools today, it is also true that there are more childrencentered educational projects, which work in line with the above mentioned transitional spaces, where children can become co-educators. So, we can find other pedagogies that base their practices on dialogical methodologies, in which the value of the relation between children and adults is highlighted. In fact, this value has been the focus of attention of some classical researchers, as it is the case of Dewey (1966) and Vygostky (1978), for whom learning can only be materialized if there is a strong relationship between both students and teachers. In the same way, the priority of this relation was very explicit in Freire's alternative proposal to the most traditional pedagogies, which, known as liberating education, wanted to propose a subversion of both the teachers' and the students' roles, through an establishment of dialogues that had the objective to get the freedom of students. Certainly, this subversion of roles is what alternative pedagogies aim to emphasize, actually, in order to get the possibility of rethinking children as co-educators. In this sense and according to Freire, teachers are not the only ones who teach, but they are taught in dialogue with the students, who teach, too, at the same time that they are being taught (Freire 1972: 53). As we can see, therefore, the full weight of learning is taken away from the teacher here and it is distributed among the students, who enjoy a more active role. Besides, "authority" is a no longer valid argument (Freire 1972: 53), as children become essential co-educators in their own learning, having more and more spaces to visualise their own contributions as well as to express their opinions from their critical, ethical and creative perspectives.

The reconceptualization of children as empowered critical, ethical and creative co-educators in dialogue with adults in schools lets us revaluate their creativity, since they base their actions on creative ways of behaving. This is the reason why we consider that, although the practice of alternative pedagogies is increasing in schools now, the tendency should be to foster them continuously in order to turn into habit pedagogies, which, as an effect of their recognition of children as co-educators, work for reinforcement of children's creativity, showing their critical and ethical thinking. It is necessary, then, to promote pedagogies for a creativity revaluation, in which children can feel themselves as intrinsically motivated co-educators, excited, interested and satisfied for what they are doing in schools and for the way in which they are doing it (Amabile 1997); pedagogies for a revaluation of creativity that benefits the flow of children's creative thinking (Csikszentmihalyi 1996) thanks to the creation 
of spaces where children can work on what they feel to be their element, it is, what is stimulating for them and what they do well (Robinson 2009). In summary, pedagogies for revaluation of creativity that, while empower children in their dialogues to adults as critical and ethical thinkers, become "the practice of freedom", thanks to which, children can manage the reality critically and creatively and discover different ways to contribute to the transformation of the world (Freire 1972: 13).

\section{Conclusions}

Children, as one of the subjugated groups, have often had a secondary position in relation to matters that have affected them. As with women, for example, their voices have usually been silenced, due to the idea that children are so lacking in experience, that they are not mature enough to take rational decisions; that they are so fragile and vulnerable, that adults always have to tell them what to do and how to do it. However, we cannot forget that strong alternative theories are emerging in childhood studies which highlight the different roles that children can play as active subjects, whose plural voices must be taken into account from their own more creative ways of acting. In this sense, ideas have been presented in this text with the aim to rethink children as empowered critical, ethical and creative co-educators in dialogue with adults. Creativity is valued for itself and we have also argued that creative thinking intra-acts with critical and ethical thinking and action. A rethinking of children has been put forward in this study, particularly in the context of formal education, that makes the case for revaluation of creativity in schools.

\section{Bibliography:}

Alderson, P.: The politics of childhoods, real and imagined. Practical application of critical realism and childhood studies, London \& New York, Routledge, Taylor \& Francis Group, 2016.

Amabile, T.: "Motivating Creativity in Organizations: on doing what you love and loving what you do", California Management Review, 40, 1 (1997) 39-58.

Biesta, G.: "Philosophy, exposure, and children: How to resist the instrumentalisation of Philosophy of Education", Journal of Philosophy of Education, 45, 2 (2011) 305-319.

Bourdieu, P. and Passeron, J. C.: Reproduction in Education, Society and Culture, London, Sage Publications, 1990. 
Burman, E.: Developments. Child, image and nation, London, New York, Routledge, 2008.

Csikszentmihalyi, M.: Creativity: flow and the psychology of discovery and invention, New York, Harper, 1996.

Dewey, J.: Democracy and education: An introduction to the philosophy of education, New York, The Free Press, 1966.

Freire, P.: Pedagogy of the oppressed, Middlesex, England, Penguin Books, 1972.

-: Pedagogy of hope, London, Continuum Publishing Company, 1994.

: Pedagogy of indignation, Boulder, Paradigm Publishers, 2004.

Gittins, D.: The child in question, New York, Palgrave McMillan, 1998.

Greene, M.: Releasing the imagination: Essays on Education, the Arts, and Social Change, San Francisco, Jossey-Bass Publishers, 1995.

Haynes, J.: "Freedom and the urge to think in Philosophy with children. Gifted Education International", Gifted Education International, 22, 2-3 (2007) 229-237

Haynes, J. and Murris, K.: “Opening up space for children's thinking and dialogue", Farhang, 69 (2009) 175-188.

-: Picturebooks, Pedagogy and Philosophy, London, Routledge, 2012.

: "Child as educator: introduction to the special issue", Studies in Philosophy and Education, 32, 3 (2013a) 217-227.

--: "The realm of meaning: imagination, narrative and playfulness in philosophical exploration with young children", Early Child Development and Care, 183, 8 (2013b) 1084-1100.

Hultqvist, K. and Dahlberg, G.: Governing the Child in the New Millenium, New York, London, RoutledgeFalmer, 2001.

Huynh, K. et al.: Children and global conflict, Cambridge, Cambridge University Press, 2015.

Kennedy, D.: Changing conceptions of the child from the Renaissance to PostModernity: A philosophy of childhood, Lewiston, New York, The Edwin Mallen Press, 2006.

----------: Philosophical dialogue with children. Essays on theory and practice, Lewiston, New York, The Edwin Mellen Press, 2010.

: "One argument for why we should listen to children", in E. Marsal et al. (eds.): Respect: How do we get there?, Zurich, Lit Verlag, 2013, pp. 35-46.

"Neoteny, dialogic education and an emergent psychoculture: notes on theory and practice", Journal of Philosophy of Education, 48, 1 (2014) $100-117$.

Kitchener, R. F.: “Do children think philosophically?", Metaphilosophy, 21, 4 (1990) 416-431. 
Kohan, W. O.: "Childhood, education and philosophy: notes on deterritorialisation", Journal of Philosophy of Education, 45, 2 (2011) 339-357.

Kronfeldner, M. E.: “Creativity naturalized”, The Philosophical Quarterly, 59, 237 (2009) 577-592.

Matthews, G.: The philosophy of childhood, Cambridge, Harvard University Press, 1996.

Murris, K.: "Philosophy with preliterate children", Thinking: The Journal of Philosophy for Children, 14, 4 (1999) 23-33.

: "Can children do philosophy?", Journal of Philosophy of Education, 34, 2 (2000a) 261-279.

---: "The role of the facilitator in philosophy enquiry", Thinking: The Journal of Philosophy for Children, 15, 2 (2000b) 40-47.

---: "Philosophy with children, the stingray and the educative value of disequilibrium", Journal of Philosophy of Education, 42, 3-4 (2008) 667685.

: "Reading philosophically in a Community of Enquiry: Challenging Developmentality with Oram and Kitamura's Angry Arthur", Children's Literature in Education, 45, 2 (2014) 145-165.

: "Posthumanism, philosophy for children, and Anthony Brown's "Little Beauty", Bookbird. A Journal of International Children's Literature, 53, 2 (2015) 59-65.

: The posthuman child. Educational transformation through philosophy with picturebooks, Oxford, Routledge, 2016a.

: "Rhodes must fall: a posthuman orientation to decolonising higher education institutions", South African Journal of Higher Education, 30, 3 (2016b) 274-294.

: "Philosophy with picturebooks", in M. A. Peters (ed.): Encyclopaedia of Educational Philosophy and Theory, Singapore, Springer Science, Business Media Sinagore. 2016c, pp. 1-7.

---------: "The philosophy for children curriculum: Resisting "Teacher proof' texts and the formation of the ideal philosopher child", Studies in Philosophy and Education, 35, 1 (2016d) 63-78.

----------: "Reading two Rhizomatic pedagogies diffractively through one another: a Reggio inspired philosophy with children for the postdevelopment child", Pedagogy, Culture \& Society, 25, 4 (2017a) 531550.

----------: "Reconfiguring educational relationality: the educator as pregnant stingray", Journal of Education, 69 (2017b) 117-138.

Olsson, L. M.: "Taking children's questions seriously: the need for creative thought", Global Studies of Childhood, 3, 3 (2013) 230-253. 
París Albert, S.:" Philosophy for making peace with children. An incentive for creativity", Convergencia. Revista de Ciencias Sociales, 75 (2017) 65-85.

Pávez Soto, I.:" Sociología de la infancia: las niñas y los niños como actores sociales", Revista de Sociología, 27 (2012) 81-102.

Pritchard, M.: "Desarrollo moral y filosofía para niños", in F. García Moriyón (ed.): Crecimiento moral y filosofía para niños, Bilbao, Desclée de Brouwer, 1998, pp. 69-112.

Robinson, K.: The Element. How finding your passion changes everything, London, Penguin Books, 2009.

Schipper, F.: "Creativity and rationality: a philosophical contribution", Reason in practice, 1, 2 (2001) 3-15.

Smith, R.: "The play of Socratic dialogue", Journal of Philosophy of Education, 45, 2 (2011) 221-233.

Storme, Th. and Vliegue, J.: "The experience of childhood and the learning society: allowing the child to be philosophically and philosophy to be childish", Journal of Philosophy of Education, 45, 2 (2011) 183-198.

United Nations: Convention on the rights of the child, United Nations, Human Rights Office of the High Commissioner, http:/www.ohchr.org/en/ professionalinterest/pages/crc.aspx. Accessed 1 January 2018, 1989.

Vansieleghem, N. and Kennedy, D.: "What is philosophy for children, What is philosophy with children-after Matthew Lipman?", Journal of Philosophy of Education, 45, 2 (2011) 171-182.

Vygotsky, L. S.: Mind in society: The development of higher psychological processes, Cambridge, Harvard University Press, 1978.

Wilson, J.:" Philosophy for children: A note of warming", Thinking, 10, 1 (1992) 17-18. 